\title{
The moderation of stock performance on the influence of corporate governance toward comprehensive income in the period of covid-19
}

\author{
Rina Pebriana ${ }^{1, *}$ M. Riduan Abdillah ${ }^{2}$, Maulida Hirdianti Bandi ${ }^{3 *}$ \\ ${ }^{1}$ Politeknik Negeri Tanah Laut \\ ${ }^{2}$ Politeknik Negeri Tanah Laut \\ ${ }^{3}$ Politeknik Negeri Tanah Laut \\ "Corresponding author.Email: maulidahirdianti@politala.ac.id
}

\begin{abstract}
This study aims to find empirical evidence regarding the moderation of stock performance on the influence of Corporate Governance on Comprehensive Income. The independent variables used in this study are corporate governance as measured by using the corporate governance index. Dependent variables in this study used comprehensive income measured using total net profit. Moderating variable in this study is the performance of stocks measured using the closing stock price. The population of this study is transportation sector companies listed on the Indonesian Stock Exchange in 2020. The sampling method in this study used saturated samples. The statistical test tool used in this study is path analysis through Warp PLS 3.0.
\end{abstract}

Keywords: Corporate Governance, Comprehensive Income, Stock Performance, Indonesia Stock Exchange.

\section{INTRODUCTION}

The Covid-19 pandemic in 2020 gives a significant impact on changes in the economic behavior of businesses that ultimately impact the economic situation both micro-scale and macro scale. Regulation from the Central Government and Local Government to implement PSBB (Large-Scale Social Restrictions) apparently makes public interest in using transportation services is also limited or constrained as a result of the turnover of some companies engaged in the transportation sector is affected significantly. Although currently the Central / Regional Government tries to implement a regulatory policy that was originally the implementation of PSBB is now a PPKM namely the Enforcement of Restrictions on Community Activities.

Quoting from online news through www.sepatah.com_(2021), it tells that Lifepal.co.id research found although the need for transportation services decreased during the pandemic, in fact there are issuers in the transportation sub-sector whose share price movements are above the performance of the Infrastructures, Utilities, and Transportation and IHSG indices. On the contrary, there are issuers whose performance is below the performance of the index. Not only the share price of transportation issuers, sales and profits of transportation companies are also affected. The declining movement of people in transportation centers triggered a decrease in GDP in the Transportation and Trade sector. The movement of people after March continues to decline to its lowest point in May 2020. After May 2020, the movement of people began to increase. But it is still not back to normal due to various restrictions on social activities. The decline in the movement of people caused GDP growth in the transportation and trade sectors to be under very deep pressure. In the second quarter of 2020, there was a decrease of $-30.84 \%$, while in the third quarter of 2020 , there was a decrease of $-16.70 \%$, although it actually increased from the previous quarter. The contraction of growth in Q3/2020 was not as deep as in Q2/2020 due to adaptation of new habits or easing of PSBB. It also contributes to improving the field performance of transportation and warehousing businesses.

Corporate governance from the perspective of regulators is a system consisting of rules, measurements and factors that control a company (Rezaee, 2007) ${ }^{[1]}$. Corporate governance is a very important variable even an interesting phenomenon to discuss let alone linked to the company's performance in terms of finance, especially the economic impact of the Covid 19 
phenomenon for companies engaged in the transportation sector. This corporate governance phenomenon has existed since financial problems hit Indonesia during the economic crisis of 1997/1998. Now Indonesia is again affected by the economic crisis due to the Covid 19 problem but not as severe as the financial situation in 1997/1998. Comprehensive income is the total net income presented in the income statement [2]. In principle, corporate governance can be used as a strong foundation to maintain the sustainability of the company and minimize negative risks such as information asymmetry, moral hazard, and others that can certainly impact the comprehensive profit of the company itself. Research [2]018 found evidence that the better corporate governance culture will have a positive effect on the company's financial performance as measured by Comprehensive Income. Signalling Theory explains that investors and shareholders will react very much if they get information on the stock market, either bad news or good news. In the midst of Covid-19 conditions various strategies are pursued by companies to maintain their financial situation. That is, stock trading is possible to be something that includes the state of being unstable. Stock performance can be measured using the closing stock price (Lai, et al. 2010) ${ }^{[3]}$. Stock performance is one indicator of market reaction. Thus, the tendency of both good news and bad news to be a signal that will be captured by investors who will eventually react and impact the company's condition, in this study is linked to the influence of corporate governance on comprehensive profit

\section{METHOD}

The population in this study is all transportation companies listed on the Indonesia Stock Exchange (IDX) in 2020. The sample selection method in this study uses saturated sample method. Sugiyono (2018) ${ }^{[4]}$ suggests that saturated samples are a sampling technique when all members of the population are used as samples. So, in this study using all transportation companies listed on the Indonesia Stock Exchange (IDX) year 2020 as a sample of this study.

The independent variables used in this study are corporate governance measured using corporate governance index (CGI) which has also been used in Siagian research, et al. $2013^{[5]}$. Corporate Governance Index (CGI) is divided into 5 groups of items consisting of right of shareholders, equal treatment of shareholders, role of stakeholders, disclosure and transparency and board responsibilities. All of these items will be checked to the company's annual report. The total number of information items expected to be found in each company based on the Corporate Governance Index (CGI) amounts to 52 items. Each item of information disclosed/found in the company's annual report based on the Corporate Governance Index (CGI) will be rated 1 . In contrast, items of undisclosed/undisclosed information found in the company's annual report based on the Corporate Governance Index (CGI) will be rated 0 . So, to obtain the Corporate Governance Index (CGI) is by summing the score of information items disclosed / found in the annual report of each company based on the Corporate Governance Index (CGI) divided by 52 (which is the total of the expected items based on the Corporate Governance Index (CGI)).

Dependent variables in this study used comprehensive income measured using total net income (Quesada,et al. 2018) ${ }^{[2]}$. Moderating variables in this study are stock performance measured using stock performance as measured using closing stock price (Lai et al. 2010) ${ }^{[3]}$.

\subsection{Model Used}

The research equations that will be tested in this study are as follows:

$\mathrm{CG}=\alpha+\beta_{1} \mathrm{LK}+e$ Model

$\mathrm{CG}=\alpha+\beta_{1} \mathrm{LK}+\beta_{1} \mathrm{LK} * \mathrm{KS}+e$ Model

\section{information:}

\section{CG : Corporate Governance}

LK : Comprehensive Income

\section{KS : Stock Performance}

$e:$ Error term, i.e. the level of suspect error in the study

This study conducted a moderation test (moderating effect). Sholihin and Atmono (2013) ${ }^{[6]}$ explained that the influence of moderation (moderating effect) occurs when a variable (in this study moderating variables used is the performance of stocks) change the strength or even the direction of the relationship of two variables ( in this study namely corporate governance to comprehensive profit) in the model. In this study, the type of moderation relationship used was the influence of continuous moderating effect where the moderating variables used in this study were measured by metric scale (interval or ratio). Below are the moderation effect models used in this study: 


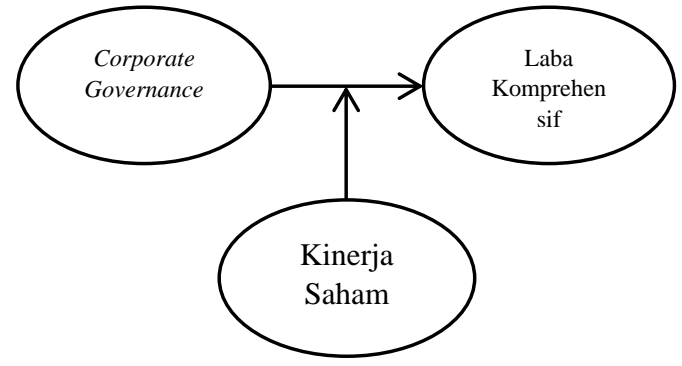

Figure 1. Moderation Effect Model

The data used in this study is secondary data in the form of annual report 2020 for check list Corporate Governance Index (CGI), financial and non-financial information contained in the website of each company as needed based on corporate governance index (CGI), data comprehensive profit can use the information contained in the financial statements in 2020 and stock performance can use the information listed from the Website Indonesia Stock Exchange (IDX). The collection of research data was conducted through a library study consisting of documents, journals, internet and other data sources to support the reference material of this study. The collection of research data is also conducted through observation of each company's website by accessing the website address of each company obtained based on the IDX Fact Book database.

\subsection{Research Data Analysis}

Hypothesis testing in this study was conducted through structural equation model (SEM) approach using Pls 3.0 Warp Software. The analysis of this research was conducted by path analysis. Some things to note to test the moderation effect using path analysis through Warp PLS 3.0 (Sholihin and Atmono, 2013), in this study testing the moderation of stock performance on the influence of corporate governance on comprehensive profit, namely:

1. Draw moderation models in Warp PLS 3.0

2. Create Moderating Links in Warp PLS 3.0

3. Testing moderation models

4. Interpretation of moderation test results:

a. Fit model indicators must be met i.e. significant

APC and ARS values with a $p$ value of < 0.001 .

b. Avif indicators must be eligible under the 5 limit. In moderation testing, AVIF should be focused because in Warp PLS use intervariable interactions (moderated regression analysis) that can likely occur multicolineerity.

c. The output value of the coefficient path and $\mathrm{P}$ values $>0.001$ indicate insignificant in order to know the moderation effect. d. Vif full colinearity value must be below 3.3

\section{RESULTS AND DISCUSSION}

The following is presented statistic testing model of the influence of corporate governance on comprehensive profit, as follows:

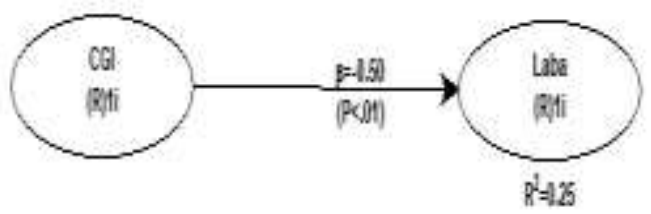

Source : Output Warp PLS (2021)

Figure 2 Test Model of The Effect of Corporate Governance on Comprehensive Profit

The following are presented the results of statistical tests on the influence of corporate governance on comprehensive profit:

Table 1 Statistical Test Results on The Effect of Corporate Governance on Comprehensive Profit

\begin{tabular}{|l|l|l|l|}
\hline Variabel & Beta & Sig & Keterangan \\
\hline $\begin{array}{l}\text { Corporate } \\
\text { Governance - Laba }\end{array}$ & $-0,502$ & $0,001 *$ & Signifikan* \\
\hline $\begin{array}{l}R \text { Square }=0,252 \\
* \text { Sig. }=0,001\end{array}$ & & & \\
\hline
\end{tabular}

Source : Output Warp PLS (2021)

The above output shows that corporate governance directly affects comprehensive profit with a significance value of less $\mathrm{p}<0.001$. Meanwhile, $\mathrm{R}$ Square showed 0.252 which means that the influence of corporate governance on comprehensive profit is only 0.252 or $20 \%$.

Furthermore, below is presented statistical testing model of the effect of moderation of stock performance on corporate governance relationship to

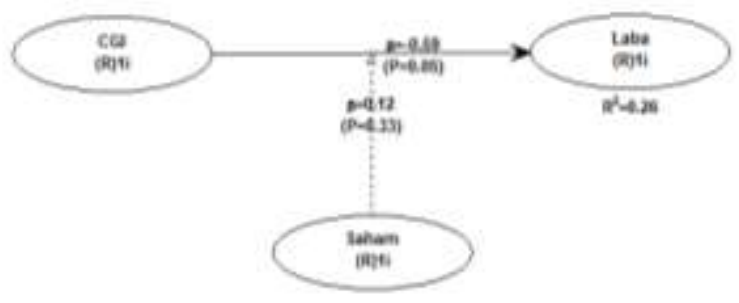

comprehensive profit, as follows:

Source : Output Warp PLS (2021) 
Figure 3 Test Model The effect of stock performance as a moderating variable on the influence of corporate governance on comprehensive income.

Here is an interpretation of some of the main outputs of moderation model test results:

Table 2 Fit Indices and $P$ values models

$\mathrm{APC}=0.356, \mathrm{P}=0.003$

$\mathrm{ARS}=0.259, \mathrm{P}=0.275$

$\mathrm{AVIF}=2.147$, Good if $<5$

Sumber : Output Warp PLS (2021)

The above output indicates that fit model indicators have been met, i.e. APC and ARS are insignificant with a $\mathrm{p}$ value of more than 0.001 . The AVIF indicator of 2,147 is eligible under the 5 limit.

The following are presented the results of the test of the effect of moderation of stock performance on the relationship between Corporate Governance and
Source : Output Warp PLS (2021)

\section{Figure 5 Multicolinearity Test Results}

The above output indicates that there is no multicolinearity related to the interaction between independent and moderating variables where the vif full colinearity value is still below the 3.3 limit

\section{Discussion}

The test results of the 1 st research model in this study support hypothesis 1 , which is to find evidence that corporate governance has a significant effect on comprehensive profit but corporate governance shows a negative direction of influence on comprehensive profit i.e. the value of $p$ value $<0.001$ with a value of $\beta=$ 0.502 . The results of this study are in line with the research siagian, et al. (2013) ${ }^{[5]}$ and Gu, et al. (2002) ${ }^{[7]}$. The implementation or implementation of corporate governance that is carried out properly as a whole system in the company will make the arrangement of monitoring and control mechanisms to the policies

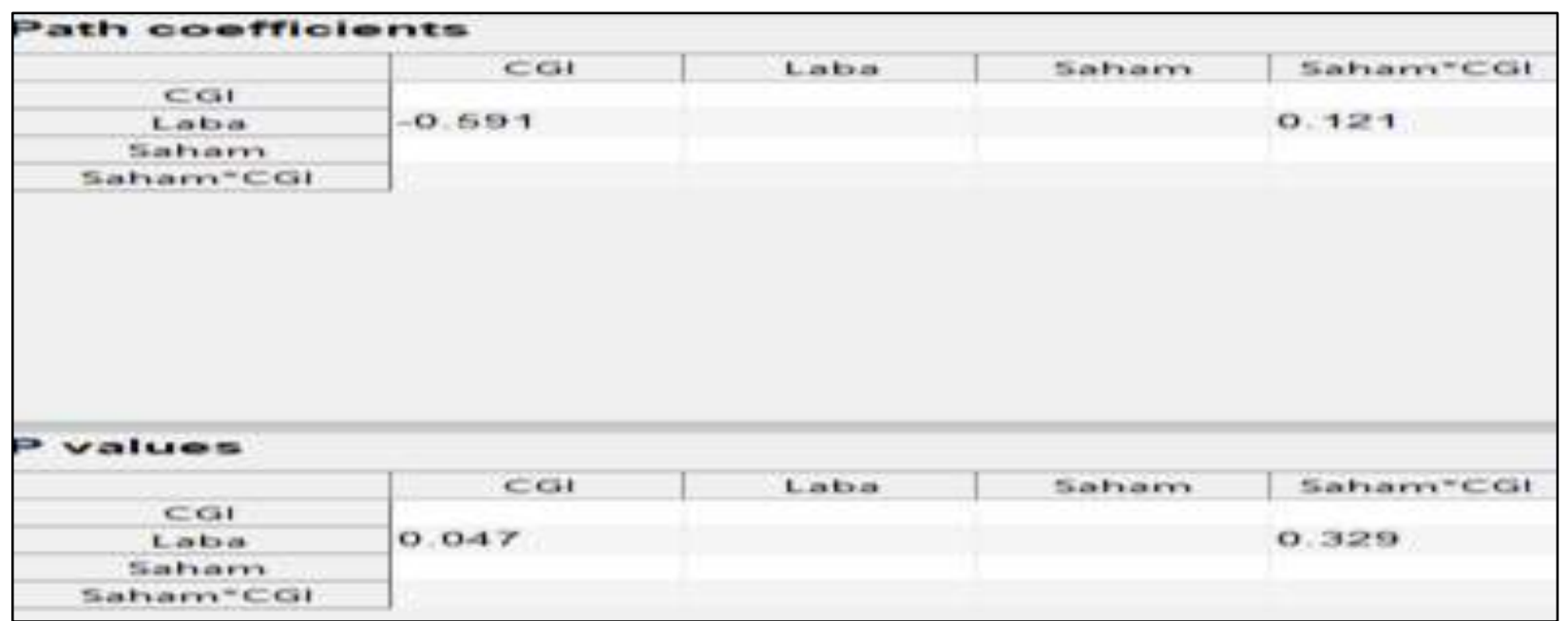

comprehensive profit:

Source : Output Warp PLS (2021)

\section{Figure 4 Moderation Effect Test Results}

The above output indicates that the moderating effect of stock performance on the relationship between Corporate Governance and comprehensive income is insignificant with a $\mathrm{p}$ value of 0.329 . These results indicate that the performance of stocks is not as variable moderating the relationship between corporate governance and comprehensive profit. carried out by the management of the company will also bemonitored and controlled very well as well as if connected with the decision-making process by the management to solely act in the best interests of shareholders who are closely related to investment issues (Siagian, et al. 2013) ${ }^{[5]}$. Corporate governance can essentially be a tool that can reduce the cause of information risk between shareholders and company management through monitoring and control functions that can ultimately be improved the company's

\begin{tabular}{|c|c|c|c|c|}
\hline & CGI & Laba & Saham & Saham ${ }^{\star} \mathrm{CGI}$ \\
\hline R-squared & & 0.259 & \\
\hline Composite reliab. & 1.000 & 1.000 & 1.000 & 1.000 \\
\hline Cronbach's alpha & 1.000 & 1.000 & 1.000 & 1.000 \\
\hline Avg. var. extrac. & 1.000 & 1.000 & 1.000 & 1.000 \\
\hline Full collin. VIF & 1.559 & 1.208 & 1.850 & 2.090 \\
\hline Q-squared & & 0.245 & & \\
\hline
\end{tabular}


information system in the context of realizing transparency and accountability of the company that ultimately impacts the more effective the company's performance. But on the other hand, Gu, et al (2002) ${ }^{[7]}$ explained that for large companies, it will face a lot of high political sensitivities than small companies where the political costs include government intervention, taxation, and various other demands so that large companies will reduce political costs by using accounting options that can reduce profits. Thus the profit generated tends to be small and not persistent and does not reflect the quality of the actual profit generated by the company. Moreover, this research period in 2020 where cases of spikes due to cases of the Covid-19 virus on a business scale is not separated from the transportation sub-sector of course becomes a contributing factor to the political cost. Thus, political costs such as government intervention, taxation, and various other demands can play a role for companies that make even though a company's corporate governance is good the tendency of the company will lower the level of persistence of its profit and vice versa, although corporate governance of a company is not good the tendency of the company will increase the level of persistence of its profit

The test results of the 2nd research model in this study did not support the 2nd hypothesis, which found evidence that the moderating effect of stock performance on the relationship between Corporate Governance and comprehensive profit was insignificant with a $p$ value of 0.329 . These results indicate that the performance of stocks is not as variable moderating the relationship between corporate governance and comprehensive profit. This study uses research data in 2020, which this research period, the stock market experienced a very sharp and drastic decline (crash) due to the impact of the global financial crisis due to the extraordinary events of the Covid-19 pandemic in the transportation sub-sector that limited the movement of consumers in the utilization of services from the transportation sub-sector so as to make the market reaction ignore or not use information about the performance of stocks in making decisions to increase profits. The results of this study are in line with the research of Rafsyanjani and Wuryani (2021) ${ }^{[8]}$ which suggests that there is a significant difference in the share price of the transportation sub-sector before and after Covid-19. In this study, transportation companies listed on the Indonesia Stock Exchange experienced a very significant decrease in performance so that investors assessed the decrease in the performance of transportation companies listed on the Indonesia Stock
Exchange. That caused the majority of the share price in transportation companies to decline significantly.

The Covid-19 pandemic not only negatively impacted the share price, but also had an effect in 2020 on the total shares traded. This is because the Covid-19 pandemic forces people to limit their activities outside the home. The implementation of social restrictions in major cities forced some people to avoid doing activities outside the home including to tourist attractions to stop the spread of the virus. This condition certainly encourages tourist attractions to be deserted and transportation company revenues to decrease. This makes investors become worried and more selective in trading shares in the company, thus making stock trading sluggish and eventually pushing the total shares traded down. The Covid-19 pandemic also caused revenues or funds in the community and investors to decline as most companies closed. This encourages investors to reduce stock transactions. Not to mention the problems in the field of health that create a dilemma between 2 sectors that need to be considered in decision making, namely more concerned about health issues but turning back economic issues and vice versa. Therefore, market reaction is more focused on health news since the beginning of the pandemic that resulted in the issue of stock performance becomes a minority in policy making considerations for the company.

\section{REFERENCES}

[1] Z. Rezaee, Corporate governance postSarbanes-Oxley: Regulations, requirements, and integrated processes. John Wiley \& Sons, 2007.

[2] E. López-Quesada and S. O. Idowu, "Corporate governance practices and comprehensive income," Corp. Gov. Int. J. Bus. Soc., 2018.

[3] S.-C. Lai, C. Lin, H.-C. Lee, and F. Wu, “An empirical study of the impact of internet financial reporting on stock prices," Available SSRN 1014140, 2007.

[4] Sugiyono, Metode Penelitian Kualitatif dan $R$ and D. Bandung: Alfabeta, 2015.

[5] F. Siagian, S. V Siregar, and Y. Rahadian, "Corporate governance, reporting quality, and firm value: evidence from Indonesia," $J$. Account. Emerg. Econ., 2013.

[6] M. Sholihin and D. Ratmono, Analisis SEM- 
PLS dengan Warp PLS 7.0 Untuk Hubungan

Penelitian Sosial dan Bisnis Edisi 2.

Yogyakarta: ANDI Yogyakarta, 2020.

[7] Z. Gu, C. J. Lee, and J. G. Rosett, "Information Environment and Accrual Volatility," AB Free. Sch. Business, Tulane Univ., pp. 1-23, 2002.

[8] R. Rafsyanjani and E. Wuryani, "Analisis Harga Saham Perusahaan Transportasi DI BEI Sebelum danSesudah Covid-19," JIKEM J. Ilmu Komputer, Ekon. dan Manaj., vol. 1, no. 1, pp. 1-9, 2021. 